UDC: $347.01(430)$

\title{
THE 19TH CENTURY GERMAN LEGAL SCIENCE AND ITS CONTRIBUTION TO CONTEMPORARY PRIVATE LAW
}

\author{
Sami Mehmeti, PhD \\ Assistant professor, \\ Southeast European University, Faculty of Law, Tetovo \\ Email: s.memeti@seeu.edu.mk
}

\begin{abstract}
Since its modern origins German law was 'learned law', a law that emanated from academic teaching and writing. The emergence of the 'learned' lawyers is intimately linked to the transition from medieval feudalism to the modern state in the later Middle Ages. The new concept of legal science developed by German lawyers near the beginning of the 19th century was a reaction to a particular methodological challenge. This challenge derived principally from the jurisprudential void left after Kant's critical philosophy had discredited the belief in the postulations and methods of natural law that had been pre-eminent the previous centuries. The German Pandectist School, which epitomized the foremost authority of German legal science at that time, took a revitalizing outlook to Roman law, in order to build a system of contemporary private law to meet the main requirements of the modern society. Its goal was to create a rigorously logical and comprehensive legal system by developing abstract and coherent concepts which, together as a whole, form a law that is supposed to be free from gaps. It introduced core legal concepts like the 'declaration of intent' and the 'legal act' in private law and it also had profound impact scholarship and legislation throughout Europe and beyond.
\end{abstract}

Keywords: Legal science, Historical school of law, conceptual jurisprudence, German civil code, private law

\section{Introduction}

Since early modern period German law was considered 'learned law', a law based on scholarly teaching and writing. German lawyers were historically typically academic or 'learned' lawyers, all of them utilizing the very same legal texts on Roman-Canon law, following the same conventional scholastic methodology and legal terminology, sharing the same intellectual upbringing, the same trust in academic study of the law and the same reverence for those in charge of studying and interpreting it, the law professors. ${ }^{1}$

\footnotetext{
1 Dawson, J. P., The Oracles of the Law, 1968, University of Michigan Law School, Ann Arbor, 1968, p. 450 .
} 
The scholars' unrivalled reputation quickly converted into tremendous impact on the lawmaking activities, both statutory and judicial. There appeared a procedural practice that would be later prescribed by legislation and that assured a cohesion of judicial decisions with prevalent scholarly opinion, the so-called 'Aktenversendung'. From the beginning of the $16^{\text {th }}$ century onwards it was usual for a court to send the documentation of a complicated case to a group of professors at a law school (Spruchkollegium), with a formal request for an opinion on the legal aspects of the dispute. ${ }^{2}$ Even though final judgment was formally delivered in the name of the court that had sent the case, the opinion of the professors was generally expressed in the form of a judgment and had binding effect on the court, meaning that the professors were de facto acting as a collegiate body of judges. The legal science was only force that could create an increasing level of legal unity in Germany. On a practical aspects the scholars clearly demonstrated that they were able of fulfilling their aim to establish legal unity throughout the country. On a theoretical level they asserted both a justification for the legitimacy of academic lawmaking and a remarkable example of the method to be used for that purpose. ${ }^{3}$

In the start of the $19^{\text {th }}$ century German jurists begun to search for a new legal science. They also began to use the term 'Rechtswissenschaft'. It meant a legal science in the limited Kantian sense, a science of positive law. ${ }^{4}$ From a Kantian standpoint, it was obvious that the new legal science had to meet at the minimum two criteria. First, in order to avoid the speculation of the School of natural law, it had to be just a science of positive law, and as a consequence its method had to be completely empirical. Second, in order to be considered a 'Wissenschaft', it should create a coherent and elaborate structure of its subject; i.e. it should be a scientific system. ${ }^{5}$

${ }^{2}$ Wieacker, F., A History of Private Law in Europe with Particular Reference to Germany, Oxford Clarendon Press, Oxford, 1995, p. 136.

3 Stefan Vogenauer, An Empire of Light? Learning and Lawmaking in the History of German Law, Cambridge Law Journal, Vol. 64, No. 2, 2005, p. 486.

4 The 'Law of Reason' had serious methodological shortcomings that it uncritically combined a variety of elements - ethics and law, positive law and ideal law, observation and speculation. The combination of these elements, led to complete methodological uncertainty. When the natural law failed to differentiate between ethics and law, it perplexed different types of standards of conduct. Kant demanded on their separation. Ethical standards are internal; i.e., they have to do with one's conscience but cannot be enforced by external authority. Legal standards are external. The natural law also failed to differentiate between the knowledge of actual rules and the search for ideal standards. This critique thoroughly tarnished the reputation of the natural law school in the eyes of the generation of legal scholars after Kant. Mathias Reimann, Nineteenth Century German Legal Science, Boston College Law Review, Vol. 31, No. 4, 1990, pp. 845-846. See also: Leonard Kriege, Kant and the Crisis of Natural Law, Journal of the History of Ideas, Vol. 26, No. 2, 1965, pp. 191-210.

5 Ibid. p. 847. 


\section{Savigny and the Historical School of Law}

The polemic on codification in the early 19th century is one of the most exciting episodes in the history of German legal scholarship. In the programmatic writings of 1814, Anthon Thibaut and Friedrich Carl von Savigny presented in the form of pamphlet their perspective on the reconfiguration of law in German territories in the post-Napoleonic period. From their debate there appeared two distinct conceptions of law and of the function of legal science. ${ }^{6}$

Thibaut's pamphlet is dominated by a powerful rhetoric attacking the chaos and confusion that characterized the German law of the day. According to Thibaut, codification would have brought an end to the fragmentation and legal particularism that still set apart Germany's legal tradition in the early 19th century. He supported the idea that the code should be the only source of law, and abrogate all prior law. The essence of Thibaut's proposal was the concept that the whole positive law must be included in the code and that every subject matter that is part of it must be regulated thoroughly and in detail. ${ }^{7}$

Thibaut thought that if the code regulates the whole law, then it is likely for the judge not to put on anything to what the lawgiver has willed. The jurist's task is practically reduced to a technical activity. Thibaut goes so far as to analogize the lawyer's profession to that of a doctor qualified of automatically treating all illnesses with a few comprehensive medications. The code was to become the lawyers' only object of study, and legal science was to be restricted only to the law put down in the code. The lawyer's scientific interest essentially comprises in systematizing that which is contained in the code's provisions. Thibaut's proposal was formulated to reject the conservative tendency that, after Napoleon's defeat, demanded a restoration of the previous legal framework, but the proposal was inadequate in offering a practical political conception of law as an another option to that tendency. ${ }^{8}$

In his celebrated essay entitled Of the Vocation of our Time for Legislation and Legal Science (Vom Beruf) Savigny not only dismissed the concept of a codification to be drafted and enacted hic et nunc, but denounced the very idea of a codification as 'inorganic', unscientific, arbitrary, and hostile to tradition. At best, it was unnecessary, at worst it would distort and stifle 'organic' development of law. Confronting Thibaut, Savigny dismissed the creation of legitimacy by way of legislation, that is, through

\footnotetext{
${ }^{6}$ According to Wieacker the polemic between Savigny and Thibaut was primarily one of personal outlooks: aristocratic culture against the politics of democracy, European tradition versus nascent national feeling; scholarship on the one hand and active practice on the other. Wieacker, op. cit. note 2 , p. 314.

${ }^{7}$ Becchi P., German Legal Science: The Crisis of Natural Law Theory, the Historicisms, and "Conceptual Jurisprudence", in Canale, D., P. Grossi, H. Hofmann (eds.), A Treatise of Legal Philosophy and General Jurisprudence Volume 9: A History of the Philosophy of Law in the Civil Law World, 1600-1900. Springer, Heidelberg, 2009. p. 197.

8 Ibid 198.
} 
the state as 'inorganic' and 'arbitrary'. ${ }^{9}$ Savigny's major argument against a speedy codification is that it would freeze the natural, historical evolution of the law. ${ }^{10}$ The law does not originate rationally from a number of universal and perpetual principles and cannot therefore be revealed through mere abstract and deductive reasoning. According to Savigny, the law is a result of historical evolution. Just like a living organism, it develops and changes over time, in the same way that 'the tree grows from its roots'. To this extent, Savigny is linked with the historical vision of Romanticism. The law is the product of a lengthy evolutionary process and of the traditions and customs of the people, but also of the more technical achievements of legal scholars.

Savigny supported Hugo's idea of seeking at the historical origins of the law as a method to discover the data of legal science. He concurred with Feuerbach and Thibaut on the idea of building a system. And he also deemed both the empiricalhistorical and the systematic methods essential. But he surpassed his fellows' theories in all three respects. First, his idea of the historical nature of law was novel and distinct. Second, his concept of the predictive system was more advanced and complicated than that of Feuerbach and Thibaut. And finally, Savigny introduced a concept for the synthesis of both the historical and the systematic methods. These three elements of Savigny's thought are the major features of the historical school he created. ${ }^{11}$

Savigny wanted his system to arise from Roman history. In his Vom Beruf, he found his interpretation. He assumed three epochs in the Roman legal history: first, a period in which the Volksgeist ${ }^{12}$ itself made law; second, a period in which jurists signify the Volksgeist, making law as its representatives; and finally, a devastating period of codification, in which incompetent jurists had edited and reused the texts of the golden age before, creating the Codification of Iustinian. According to Savigny it was an unsatisfactory outcome of premature codification. He considered codification a work of a people in cultural demise. Germany should learn from the analogy of the Roman legal history: Germany was as yet in the period analogous to the second

9 Gerhard Dilcher, The Germanists and the Historical School of Law: German Legal Science between Romanticism, Realism, and Rationalization, Rechtsgeschichte - Legal History Rg 24, 2016, p. 26.

10 Hegel thought that history evolved towards a final purpose and end. Through its history, a nation's spirit is formed. Once that development is complete, history has run its course. For Savigny, the same applies to the nation's 'legal spirit'. He believed that the final stage of the legal development of the German nation has not been reached yet. Lesaffer R., European Legal History: A Cultural and Political Perspective, Cambridge University Press, Cambridge, 2009, p. 467.

11 Reimann, op. cit. note 4, p. 852.

12 The concept of the Volksgeist, introduced by Savigny, was created to resist the ideas of the French Encyclopedists of the $18^{\text {th }}$ century relating to the dominance of public opinion and will. From the begining of natural law, the Encyciopedistes had created the supremacy of rational public opinion and will, based on the rational and active consciousness of self-determining individuals. The goal of Savigny's alienating theory of the Volksgeist was to silence and neutralize such public opinion and public will. Mitchell Franklin, The Kantian Foundations of the Historical School of Law of Savigny, Revista Juridica de la Universidad de Puerto Rico, Vol. 22, No.1, 1952-1953, 70. 
period of Rome, the period in which jurists made law as the representatives of the VoIk; consequently, the German jurists must ignore the call of the supporters of codification. ${ }^{13}$

Savigny's 'contemporary Roman law' abundantly includes the norms of ancient Roman law, especially that of the classic period, though utilizing a conceptual outlook developed by natural lawyers. ${ }^{14}$ His history of Roman law was restricted to private law and it is mostly an intellectual history of Roman legal science, and his system of Roman law was designed on ideas, not rules in practice. However, Savigny's critics regarded the Roman law, an unsuitable foundation for modern law. Moreover, Roman law was, in spite the reception during the Renaissance, the legacy of a foreign and ancient culture. Germany required a modern system of law to fulfil its current needs. ${ }^{15}$

Savigny thought that legal science was achievable by means of a combination of the historical and the systematic method. The historical research provided the material (the fundamental principles revealed over time) to which the system then gave the appropriate scientific form. The two methods indeed sought to attain the same goal, though in different dimensions. It was the real combination of both methods that made Savigny's concept "truly scientific.". ${ }^{16}$ For Savigny, legal science must never be isolated from real legal relations, which constitute the driving force of this science, and this led him to create a crucial link between the theory and the practice of law. Savigny's most instantaneous result was the perfection of the systematic study of Roman law. All German legal scholars after Savigny built on his work, but several authors developed separate aspects of Savigny's conceptions in different lines. ${ }^{17}$ Legal science split mostly along the two directions that were foreshadowed in Savigny's approach. One split related to the method used grouped the legal scholars into systematizers and historians. The other division related to the material analyzed and divided legal scholars into Romanists and Germanists. The two most distinguished

13 Whitman, J. Q., The Legacy of Roman Law in the German Romantic Era: Historical Vision and Legal Change, Princeton University Press, Princeton NJ, 1990., pp. 126-127.

14 The Tendency 'Back to the Sources' meant returning to the text of Corpus Iuris seen from the perspective that the development Roman law had taken in antiquity, to which the rediscovery of the Institutes of Gaius (1816) had brought new understanding. It meant eliminating all interpretations, changes and novelties that had been introduced in theory and practice since the Middle Ages, and rejection of the mistakes that legal scholars had made for centuries. Helmut Coing, German "Pandektistik" in Its Relationship to the Former "Ius Commune", The American Journal of Comparative Law, Vol. 37, No. 1, 1989, p. 13.

15 Reimann, op. cit. note 4, p. 868.

16 Ibid. p. 856.

17 The rules of interpretation formulated by Savigny are used so routinely that the majority using them do not know who developed them. Condensed versions of the concepts developed by Savigny were found even in the legal text-books of socialist countries. Karl A. Mollnau, The Contributions of Savigny to the Theory of Legislation, The American Journal of Comparative Law, Vol. 37, No. 1, 1989, p. 82. 
scholars after Savigny were conceptual jurists Georg Friedrich Puchta and Rudolf von Jhering. Each represents a different version of this approach. ${ }^{18}$

\section{Puchta and Jhering}

The leading figure of the $19^{\text {th }}$ century German legal science was Georg Friedrich Puchta (1798-1846), Savigny's successor on the chair for Roman law at the University of Berlin. He faithfully followed his predecessor in the idea that the historical and the systematic elements were indispensable for legal science. However, his conceptual approach departed from that of Savigny. Puchta maintained that following a rigorous study, the role of legal science was to identify the hierarchical relationship between legal categories, in order to reveal the internal and logical coherence of the norms of positive law, even if such coherence is not straightforward in the norms themselves. He is regarded the founding father of doctrinal positivism in the form of 'jurisprudence of concepts', one of the most important approaches of late $19^{\text {th }}$ century German legal science. ${ }^{19}$

Puchta was criticized because the legal science promoted by him would give rise to a scientific law disconnected from life, and the law's inherent historicity would hence be completely replaced with abstract conceptualizations lacking any proper substratum. Henceforth, and for a long time afterwards, Puchta with his 'conceptual pyramid' or what he himself labeled a 'genealogy of concepts' has been called responsible for all of the drawbacks of legal formalism. ${ }^{20}$ The notion of 'pure science' is pushed to extremes in Puchta, and the jurists' theoretical activity is consequently kept clearly separated from their practical activity. The originality of Puchta's outlook thus lies excatly in what he has frequently been criticized for; that is, in emphasizing the requirement for a legal science effectively separated from the jurists' other activities. $^{21}$

Puchta regarded his era prepared for the supremacy of legal science. As a consequence, the jurists must not only systematize the existing legal material, but make the new scientific law. He showed a sort of anti-judicial tendency straight into his interpretation of the history of Roman law by concentrating on the Roman practice of separating the decision making in legal cases between praetor and judge (iudex). ${ }^{22}$ "Our entire mode of legal thinking," Puchta wrote, "is based on Roman jurisprudence. Indeed, without Roman law, no scholarship, and therefore no productive lawmaking, would be possible". According to Puchta, hostility to Roman law was a "forgivable

\footnotetext{
18 Reimann, op. cit. note 4, p 859.

19 Padoa-Schioppa, A., A History of Law in Europe From The Early Middle Ages to the Twentieth Century, Cambridge University Press, Cambridge, 2017, p. 527.

${ }^{20}$ Becchi, op. cit. note 7, 219.

21 Ibid. p. 223.

22 Whitman, op. cit. note 13, p. 130.
} 
human weakness', but Roman law was indeed a Weltrecht, a global law, and had conclusively established itself in Germany. The age of Juristenrecht had arrived. ${ }^{23}$

The conceptual jurisprudence reached its culmination in the theories of Rudolf von Jhering. He is probably the most prominent German jurist of the $19^{\text {th }}$ century, with the exception Friedrich Carl von Savigny, with the greatest international influence. According to Hasso Hofmann, 'Rudolf von Jhering stands for an epoch making change in 19th century legal thought: from an autonomous construction of legal rules and institutes of law to an analysis of social reality, from the logical existence of legal concepts to the instrumental character of law in the service of individual and social interests, from the freedom of human will to the natural laws of causally determined reality, from an idealistic notion of law to its naturalistic explanation, from the ideal of justice to social eudaemonism, from the logical formalism of a jurisprudence of concepts to the legal sociology of the social purposes of law, from the ideal world of law to life. ${ }^{24}$

Jhering's scholarship is regularly divided into two phases. In his first phase, which approximately spans from 1842 to 1860 , he was primarily a Roman lawyer who accepted and was under the influence from the teachings of Savigny and Puchta. ${ }^{25}$ Jhering wrote in first phase a great Roman law treatise, the uncompleted three-volume The Spirit of the Roman Law (Geist des römischen Rechts: 18521865). In the first volume of Geist, Jhering is increasingly critical of Savigny: ${ }^{26}$ the idea that law originates from and is organically linked to the spirit of the people, an idea which Jhering took for granted when he was university student, and which influenced him for many years, Jhering later woud regard incompatible with the fact that German law was based significantly upon Roman legal ideas. By contrast, the conceptual jurisprudence of Puchta directly inspired the early Jhering. ${ }^{27} \mathrm{He}$ departed from Puchta and Savigny when he claimed the liberation of legal science from the

\footnotetext{
23 Ibid. p. 123.
}

24 Hasso Hofmann, From Jhering to Radbruch: On the Logic of Traditional Legal Concepts to the Social Theories of Law to the Renewal of Legal Idealism, in Damiano Canale, Paolo Grossi, Hasso Hofmann (eds.), A Treatise of Legal Philosophy and General Jurisprudence Volume 9: A History of the Philosophy of Law in the Civil Law World, 1600-1900, Springer, Heidelberg, 2009, p. 301.

25 Jhering in his early works formulated this further as 'natural-historical method' following models of the creation of systems in the natural sciences, but criticized them after his 'conversion' with biting satire and thus introduced a negative association to the term jurisprudence of concepts. Dilcher, op. cit. note 9, p. 40.

26 Even though Jhering's Geist is critical of Savigny, it does not mean outright rejection of Savigny's ideas. Jhering accepted that the history and mentality of people would play a role in determining how law develops. But he insisted that legal development is attributable to peoples' efforts to achieve objectives through law. Neil Duxbury, Jhering's Philosophy of Authority, Oxford Journal of Legal Studies, Vol. 27, No. 1, 2007, p. 31.

27 Ibid., p. 6 . 
substance of Roman law, and when he provided conceptual jurisprudence with an unusually naturalist form. ${ }^{28}$

Jhering strongly denounced the contradiction between the conviction that law emanated from the spirit of the people and the practice of law as a science. He placed his 'theory of development' against the Volksgeist and its emancipation. He claimed that in three historical phases, which Jhering specifically called "systems" and recognized as the original law of the period of kings, the ius civile of the Republic and the ius gentium of the universal and cosmopolitan Empire, Roman law had overcome the purely Roman and transitory components and had allowed its 'constituting spiritual factors' to become known as general 'higher principles of law' ${ }^{29}$ As a domain for intellectual operation, Jhering showed deep admiration for the classical Roman law. The objective of his "Spirit of the Roman Law" was to refine the essence of the classical jurists' methods in order to use them for 'general science of the nature and manifestations of law as such' ${ }^{30}$ Jhering aimed to assimilate the methodological essence of Roman law but to put an end to the blind adherence to its substance.

\section{Pandektenrecht and the German Civil Code}

The German legal science reached its high water-mark with Bernard Windscheid, whose three-volume treatise of Lehrbuch des Pandektenrechts was published in seven revised editions. The influence of this treatise can be comparable with that of the Accursius in the late medieval. ${ }^{31}$ It was a magnum opus of summation, extracting from the existing mass of legal texts the most valuable and important notions, concepts and ideas, abandoning the unimportant or outdated ones, and summarizing into highly workable form the intellectual product of previous decades. In the same way as Accursius, the main asset of Windscheid was not his inventiveness. His Lehrbuch des Pandektenrechts were adopted as the formal source of law in Greece. They were and still are the foremost reference for those seeking access to Pandectist scholarship. Windscheid's consideration for the needs of practice and his extensive references to court cases made his treatise valuable to practitioners as well. In the

28 The jurisprudence of concepts was superseded by the jurisprudence of interests, developed predominantly by Philipp Heck. What is exceptional about this school is that it created one of the very few methodological theories which succeeded to have a wider impact on legal practice. The practical impact of the jurisprudence of interests may be as a result of the lack of theoretical depth which is sometimes associated with it. Kischel, U., Comparative Law, Oxford University Press, Oxford, 2019, p. 403.

${ }^{29}$ Hofmann, op. cit. note 24, p. 303.

30 Reimann, op. cit. note 4, p. 862.

31 Windscheid called the school founded by Savigny as the heir of the humanists. Similar to the humanists, the German jurists comprehended the historical context of the texts. Nevertheless, they comprehended better the historical meaning of the texts by understanding the principles underlying them. Gordley, J., The Jurists: A Critical History, Oxford University Press, Oxford. 2013, p. 203. 
seven revised editions published until 1892 he continually put on new material and included the views of others. According to Dawson, he had an objective, detailed, and insightful thought which ranged over all main areas of private law and assembled it all in a complex, complete and organized system. ${ }^{32}$

The German civil code (BGB) is considered an epitome of the German legal science and a great monument of the art of legislation. BGB is more linear than either the French or Austrian codes and it features significant legal novelties which deserve to be mentioned: the principle of contractual freedom, the general action for unjust enrichment, the discipline on errors in contracts, important general clauses which consist in the code's express reference to some general principles such as correctness, good faith, just cause, reasonableness, proportionality and others. In the twentieth century, the use of the general clauses would enable a more flexible and contemporary interpretation of aging articles of the Code, in accordance with the development of legal practice, customs and the economy. ${ }^{33}$ Moreover, the abstract real contract doctrine which is included in the German Civil Code is a typical example of the practical application of the ideas and concepts of the Historical school and the Pandectists. ${ }^{34}$

The BGB was clearly seen as the decisive moment in German legal history, a dividing line between the new and the old law. Few scholars continued to be passionately interested of the 'vital connection which ties the past to the present'. The codification was based on the most advanced and sophisticated pandectist scholarship and thus it did not need, in contrast to all previous codifications, a legal theory beyond itself that would have constituted a higher degree of reflection and to which it would have had to be intellectually related. Nevertheless, Roman law to contemporary jurists was bound to give the impression of being as something historically conditioned which could be left to legal historians. ${ }^{35}$ The unprecedented success of the science of private law during the $19^{\text {th }}$ century thus led to a detachment from its basis. That is one of the reasons why the belief that the world of private law was made up only of the BGB became more popular. ${ }^{36}$

32 Dawson, op. cit. note 1, p. 459.

33 Padoa-Schioppa, op. cit. note 19, p. 557.

34 Andreas Rahmatian, Friedrich Carl von Savigny’s Beruf and Volksgeistlehre, The Journal of Legal History, Vol. 28, No. 1, 2007, p. 17.

35 In the late $19^{\text {th }}$ and early $20^{\text {th }}$ century, the studies on German private law assumed that the legal doctrines should be integrated with their historical aspects, a methodical tradition from the historical school. Under the influence of Franz Wieacker, the history of private law became more and more a history of legal scholarship, and it was no longer particularly interested in the substantive private law. Kjell Å Modéer, Abandoning the Nationalist Framework: Comparative Legal History, in Pihlajamäki, H.;, Dubber M. D.; Godfrey M.; (eds.), The Oxford Handbook of European Legal History, Oxford University Press, Oxford, 2018, p. 745.

${ }^{36}$ Zimmermann, R., Roman Law, Contemporary Law, European Law, Oxford University Press, Oxford, 2001 p. 42. 


\section{The Influence of German Legal Science}

The influence of the German legal science reached far beyond the boundaries of Germany. It overshadowed the exegetical schools and gave new life to legal theory in many European countries, especially Italy, France, and Austria. The BGB was much admired on all sides, more possibly abroad than in Germany, but it influenced only legal theory and doctrine. ${ }^{37}$ It is the General Part which included the doctrinal ideas passing to other lands and other systems. The German historical school influenced John Austin in moderate degree. One would expect some influence of Savigny's Volsgeist doctrine on Sir Henry Maine's Ancient Law. ${ }^{38}$ Maitland paid tribute to Savigny for having advanced the study of the development of law and institutions. ${ }^{39}$ Savignian ideas had some impact on the American law as well. It shaped the Restatement of Agency. ${ }^{40}$ It is thought that his compelling arguments against codification in Germany had a pivotal decisive role in the defeat of the first codification project in 19th century USA, the New York Civil Code. ${ }^{41}$ Nonetheless, the abuse of Savigny's Volksgeist theory by nineteenth-century German nationalism and by the National Socialists in the twentieth century may have been instrumental in the rather low opinion about Savigny in the common law world, where his great works in doctrinal law and theory, which might have impacted in rectifying this image, had minor importance. ${ }^{42}$

A remarkable similarity to the $19^{\text {th }}$ century circumstances can be seen today in the debates about a European civil code that originates from an also largely speculative concept of the tradition of ius commune based on Roman law based, apparently legitimized by current legal historical studies. One of the leading representatives of the 'ius commune seekers', Reinhard Zimmermann, emphasizes that there was once a European legal culture based on a common legal science that used the same sources of Roman-Canon law and contained common legal principles. ${ }^{43}$ In a similar

37 There was very little practical reception of the BGB, at any rate very much less than of the Code civil a century earlier. Zweigert, K. and Kötz H., An Introduction to Comparative Law, 3rd ed., Oxford University Press, Oxford, 1998, p. 154.

38 Stefan Riesenfeld, The Influence of German Legal Theory on American Law: The Heritage of Savigny and His Disciples, 37 American Journal of Comparative Law, 1989, p. 7.

39 Rahmatian, op. cit. note 34, pp. 23-24.

40 Riesenfeld, op. cit. note 38, p. 4.

${ }^{41}$ Mathias Reimann, The Historical School Against Codification: Savigny, Carter, and the Defeat of the New York Civil Code, American Journal of Comparative Law, Vol. 37, No. 1, 1989, p. 96.

42 According to Rahmatian, Savigny's Beruf may be one of the finest contributions any legal writer has ever made to the treasury of German prose, but it is not always written in the lucid and concise style of, say, the British and French writers of the Enlightenment, and appears in a few places as a text of almost mystic obscurity. Rahmatian, op. cit. note 34, pp. 3-23.

43 Reinhard Zimmermann, Roman Law and European Culture, New Zealand Law Review, Vol. 19, No. 2, 2007, pp. 366-70. 
way to Savigny's historical school it is claimed that legal science should re-establish the link with history, and such historical research will unveil the general intellectual implications that shaped common legal concepts principles as a lasting product of European culture ${ }^{44}$ Zimmermann indicates that Roman law, through its history, could be a perfect example in confirming how a common legal tradition may be established through an intellectual integration. Rather than specific laws or norms, he speaks of a common European legal culture that was based on legal scholarship. ${ }^{45}$

\section{Conclusion}

Since early modern period the German legal science was only force capable of creating a minimum level of legal unity throughout the country. The polemic on codification in the early 19th century is one of the most exciting episodes in the history of German legal scholarship. In the programmatic writings of 1814, Anthon Thibaut and Friedrich Carl von Savigny presented in the form of pamphlet their perspective on the reconfiguration of law in German territories in the post-Napoleonic period. Thibaut supported the idea that the whole positive law must be included in the code and that every subject matter that is part of it must be regulated thoroughly and in detail. Savigny not only dismissed the very idea of a codification as 'inorganic', unscientific, arbitrary, and hostile to tradition. He believed that the law is a result of historical evolution. Savigny thought that legal science was achievable by means of a combination of the historical and the systematic method. The historical research provided the material to which the system then gave the appropriate scientific form. All German legal scholars after Savigny built on his work, but several authors developed separate aspects of Savigny's conceptions in different lines.

Georg Puchta is considered the founder of doctrinal positivism in the form of 'jurisprudence of concepts', one of the fundamental approaches of late $19^{\text {th }}$ century German legal science. In Puchta, The notion of 'pure science' is pushed to extremes, and the jurists' theoretical activity is consequently kept clearly separated from their practical activity. departed from Puchta and Savigny when he claimed the liberation of legal science from the substance of Roman law, and when he provided conceptual jurisprudence with a naturalist form.

The BGB was clearly seen as the decisive moment in German legal history, a dividing line between the new and the old law. It was based on the most advanced and sophisticated pandectist scholarship. It has had profound influence in legal theory and doctrine in Italy, France, and Austria. The ideas of main representatives of German legal science still exercise influence on the creation of a new European ius commune and a European civil code based on the Roman law legacy.

\footnotetext{
${ }^{44}$ Rahmatian, op. cit. note 34, pp. 17-18.

45 Tuori, K.; Björklund, H.; (eds). (2018). Roman Law and the Idea of Europe, Bloomsbury Academic, Helsinki, 2018., p. 3.
} 


\section{REFERENCES}

\section{Books}

1. Canale, D., P. Grossi, H. Hofmann (eds.), A Treatise of Legal Philosophy and General Jurisprudence Volume 9: A History of the Philosophy of Law in the Civil Law World, 1600-1900. Springer, Heidelberg, 2009.

2. Dawson, J. P., The Oracles of the Law, 1968, University of Michigan Law School, Ann Arbor, 1968.

3. Gordley, J., The Jurists: A Critical History, Oxford University Press, Oxford. 2013.

4. Kischel, U., Comparative Law, Oxford University Press, Oxford, 2019.

5. Lesaffer R., European Legal History: A Cultural and Political Perspective, Cambridge University Press, Cambridge, 2009.

6. Padoa-Schioppa, A., A History of Law in Europe From The Early Middle Ages to the Twentieth Century, Cambridge University Press, Cambridge, 2017.

7. Pihlajamäki, H.; Dubber M. D.; Godfrey M.; (eds.), The Oxford Handbook of European Legal History, Oxford University Press, Oxford, 2018.

8. Tuori, K.; Björklund, H.; (eds). (2018). Roman Law and the Idea of Europe, Bloomsbury Academic, Helsinki, 2018.

9. Whitman, J. Q., The Legacy of Roman Law in the German Romantic Era: Historical Vision and Legal Change, Princeton University Press, Princeton NJ, 1990.

10. Wieacker, F., A History of Private Law in Europe with Particular Reference to Germany, Oxford Clarendon Press, Oxford, 1995.

11. Zimmermann, R., Roman Law, Contemporary Law, European Law, Oxford University Press, Oxford, 2001.

12. Zweigert, K. and Kötz H., An Introduction to Comparative Law, 3rd ed., Oxford University Press, Oxford, 1998

\section{Journals}

1. Andreas Rahmatian, Friedrich Carl von Savigny's Beruf and Volksgeistlehre, The Journal of Legal History, Vol. 28, No. 1, 2007, pp. 1-29.

2. Gerhard Dilcher, The Germanists and the Historical School of Law: German Legal Science between Romanticism, Realism, and Rationalization, Rechtsgeschichte - Legal History Rg 24, 2016, pp. 20-72.

3. Helmut Coing, German "Pandektistik" in Its Relationship to the Former "Ius Commune”, The American Journal of Comparative Law, Vol. 37, No. 1, 1989, pp. 9-15.

4. Karl A. Mollnau, The Contributions of Savigny to the Theory of Legislation, The American Journal of Comparative Law, Vol. 37, No. 1, 1989, pp. 81-93.

5. Leonard Kriege, Kant and the Crisis of Natural Law, Journal of the History of 
Ideas, Vol. 26, No. 2, 1965, pp. 191-210.

6. Mathias Reimann, Nineteenth Century German Legal Science, Boston College Law Review, Vol. 31, No. 4, 1990, pp. 837-897.

7. Mathias Reimann, The Historical School Against Codification: Savigny, Carter, and the Defeat of the New York Civil Code, American Journal of Comparative Law, Vol. 37, No. 1, 1989, pp. 95-120.

8. Mitchell Franklin, The Kantian Foundations of the Historical School of Law of Savigny, Revista Juridica de la Universidad de Puerto Rico, Vol. 22, No.1, 1952-1953, pp. 64-89.

9. Neil Duxbury, Jhering's Philosophy of Authority, Oxford Journal of Legal Studies, Vol. 27, No. 1, 2007, pp. 23-47.

10. Reinhard Zimmermann, Roman Law and European Culture, New Zealand Law Review, Vol. 19, No. 2, 2007, pp. 341-372.

11. Stefan Riesenfeld, The Influence of German Legal Theory on American Law: The Heritage of Savigny and His Disciples, American Journal of Comparative Law, Vol. 37, No. 1, 1989, pp. 1-7.

12. Stefan Vogenauer, An Empire of Light? Learning and Lawmaking in the History of German Law, Cambridge Law Journal, Vol. 64, No. 2, 2005, pp. 481-500. 